\title{
Effect of treatment on erythrocyte phosphoribosyl pyrophosphate synthetase and glutathione reductase activity in patients with primary gout
}

\author{
J BRAVEN, ${ }^{1}$ T R HARDWELL, ${ }^{2}$ P HICKLING ${ }^{3}$ AND M WHITTAKER 4
}

From the ${ }^{I}$ Department of Environmental Sciences, Plymouth Polytechnic, Devon; the ${ }^{2}$ Pathology Department, Torbay Hospital, Torquay, Devon; the ${ }^{3}$ Department of Rheumatology, Plymouth General Hospital, Plymouth, Devon; and the ${ }^{4}$ Department of Chemistry, Exeter University, Exeter, Devon

SUMMARY The activities of erythrocyte phosphoribosyl pyrophosphate (PRPP) synthetase and glutathione reductase (GTR) were studied in 26 patients with primary gout who were receiving no treatment or treatment with either allopurinol or azapropazone, and compared with the activity in a group of healthy controls. The activity of PRPP synthetase was significantly higher in the gout group and was not influenced by either drug. No significant difference in the activity of GTR was observed. The failure of either drug to suppress the increased activity of PRPP synthetase associated with gout is discussed.

Key words: allopurinol, azapropazone, enzymic activity.

The biochemical observation most frequently associated with primary gout is the excessive production of uric acid, which may be attributed to the formation of increased amounts of phosphoribosyl pyrophosphate (PRPP). An excessive amount of PRPP not only stimulates purine biosynthesis but nullifies the allosteric control mechanism of this metabolic pathway by the purine nucleotides. The latter are feedback inhibitors of the enzyme PRPP glutamine amidotransferase (EC 2.4.2.14), which catalyses the first stage of de novo purine biosynthesis. An increase of erythrocyte PRPP synthetase (EC 2.7.6.1) has been reported in individuals with familial gout ${ }^{12}$ and in 54 patients with primary gout ${ }^{3}$ when compared with healthy individuals. The effect of treatment on the activity of this enzyme has not to our knowledge been studied.

Conflicting reports of the changes in erythrocyte GTR (EC 1.6.4.2) activity in primary gout compared with healthy individuals have been published. An increase in enzymic activity has been reported by Long, ${ }^{45}$ whereas others found a decrease. ${ }^{3}$

Previous studies of the two enzymes have not paid due attention to the clinical uniformity of patient

Accepted for publication 13 May 1986.

Correspondence to Dr J Braven, Plymouth Polytechnic, Department of Environmental Sciences, Drake Circus, Plymouth, Devon PL4 8AA. selection. It was therefore decided to investigate the activities of both erythrocyte enzymes in two groups of fasting individuals - one having primary gout and the other healthy controls. The blood samples were taken from patients and controls in the early morning then dispatched and processed under analogous conditions. Additionally, the effect of treatment with either allopurinol or azapropazone on the activities of the two enzymes was studied.

\section{Patients and methods}

\section{S U B J E C T S}

Twenty six patients (mean age 60 years, range 41-77) were recruited from the rheumatology clinic. They were diagnosed as having primary gout after excluding secondary causes and then applying the following criteria: (a) typical attacks of gouty arthritis and $(b)$ serum uric acid levels in excess of $420 \mu \mathrm{mol} / \mathrm{l}$ at some time during the course of their disease. The duration of their gout from the initial attack varied from one to 35 years. Fifteen patients had classical radiological changes in the affected joints and five had skin tophi. Ten had a positive family history of gout. Only four were taking diuretics at the time of the study: one frusemide, two addactide, and one amiloride and hydrochlorothiazide (moduretic). 
Eighteen patients were taking gout prophylactics at the time of the study: 10 allopurinol, seven azapropazone, and one taking both drugs. After full informed consent these patients stopped their treatment for one week and the enzyme assays were repeated. Ten patients had at least one first degree relative with gout.

The mean age of the eight male controls was 48 years (range 46-51).

\section{SAMPLE COLLECTION}

The subjects fasted overnight for at least 10 hours. Whole blood $(10 \mathrm{ml})$ was collected by venepuncture into plastic tubes containing lithium heparin and dispatched to the laboratory, where they were processed within three hours of collection. The samples were centrifuged at $1000 \mathrm{~g}$ for $10 \mathrm{~min}$ and the plasma and buffy coat separated. The packed red cells were washed thrice with physiological saline and centrifuged at $1000 \mathrm{~g}$ for $10 \mathrm{~min}$. After the final wash the original volume of blood was restored by adding physiological saline to the packed cells.
PREPARATION OF HAEMOLYSATE

One millilitre of the homogeneous cell suspension was added to $8 \mathrm{ml}$ of ice cold water and mixed for

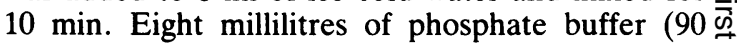
$\mathrm{mmol} / \mathrm{l}, \mathrm{pH} 7 \cdot 4)$ containing disodium ethylene- $\mathrm{O}$ diaminetetra-acetate (EDTA) $(4 \mathrm{mmol} / \mathrm{l})$ was added $\overline{ }$ to the 'laked' cells and the mixing continued for $10 \mathrm{~min}$ followed by centrifugation at $1000 \mathrm{~g}$ for $\stackrel{\mathbb{Q}}{\varrho}$ $10 \mathrm{~min}$. Before the PRPP synthetase assay the supernatant was diluted $1: 8.5$ with phosphate buffer $(67.5 \mathrm{mmol} / \mathrm{l}, \mathrm{pH} 7.75)$ containing disodium adenosine triphosphate (ATP) and $\mathrm{MgCl}_{2}$ to give a $\overrightarrow{\vec{\omega}}$ haemolysate preparation of $0.65 \mathrm{mmol} / \mathrm{l}$ ATP, $1.25 \mathrm{mmol} / \mathrm{l} \mathrm{Mg}^{2+}, \quad 0.22 \mathrm{mmol} / \mathrm{l}$ EDTA in $64.5 \mathrm{mmol} / \mathrm{l}$ phosphate buffer $(\mathrm{pH} 7 \cdot 75)$. The protein content of the supernatant of the initial 1 in of 17 haemolysate was measured on a Guildford Staser $-\overrightarrow{-}$ III using the biuret reagent and a standard reference serum.

ENZYME ASSAYS

All assays were performed on the day of collection

Table 1 Mean PRPP synthetase and GTR activities in patients with gout and in the control group

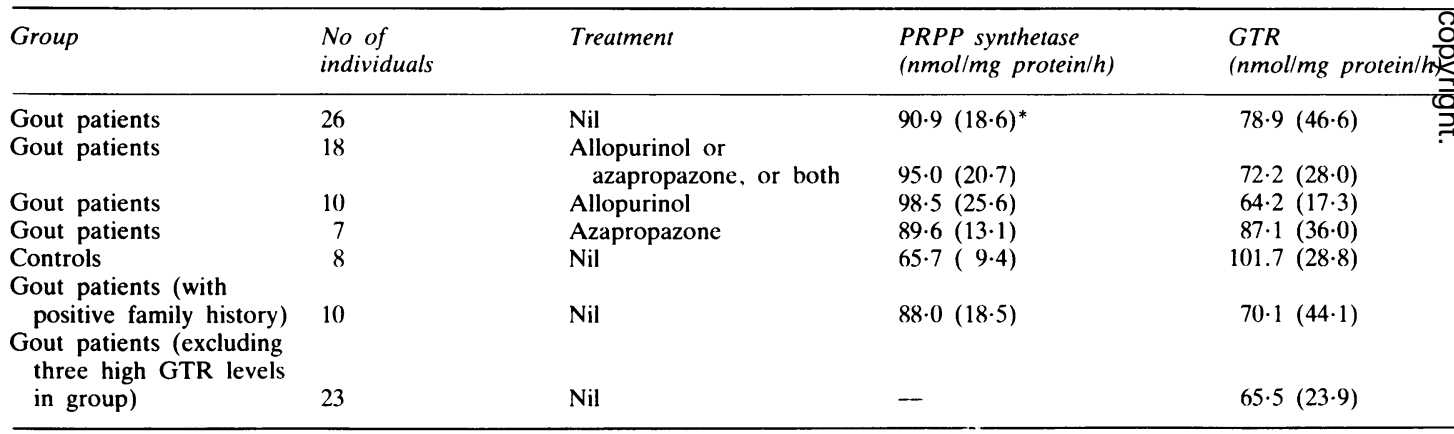

${ }^{*}$ Values are mean $(\mathrm{SD})$.

Table 2 Comparisons of PRPP synthetase activities and GTR activities according to clinical group

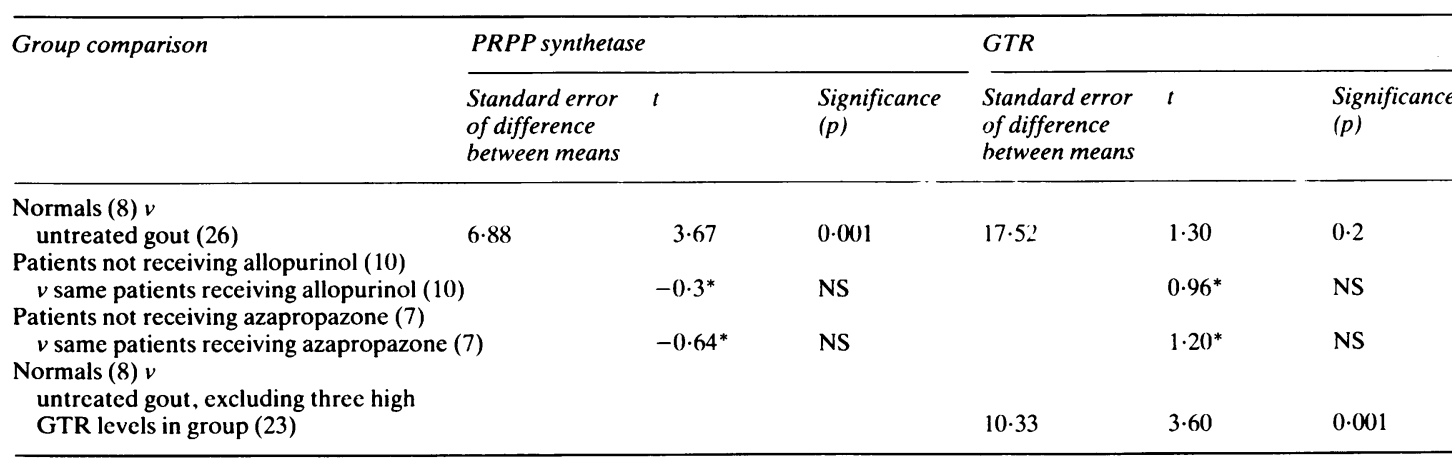

*Analysed using a $t$ test for paired data. 
Table 3 Mean serum uric acid (umolll) in patients with gout before and after treatment

\begin{tabular}{|c|c|c|c|}
\hline $\begin{array}{l}\text { No of } \\
\text { patients }\end{array}$ & No treatment & Treatment & Drug \\
\hline 18 & $425(107.9)^{*}$ & 317 (108) & $\begin{array}{l}\text { Allopurinol or aza- } \\
\text { propazone, or both }\end{array}$ \\
\hline 10 & $421(112 \cdot 3)$ & $334(100)$ & Allopurinol \\
\hline 7 & $420(113 \cdot 1)$ & 305 (122) & Azapropazone \\
\hline 1 & 508 & 204 & $\begin{array}{l}\text { Allopurinol and aza- } \\
\text { propazone }\end{array}$ \\
\hline
\end{tabular}

*Values are mean (SD).

Table 4 Mean cholesterol and serum triglyceride levels (mmolll) in control group and in patients with gout before and after treatment

\begin{tabular}{llll}
\hline $\begin{array}{l}\text { No of } \\
\text { patients }\end{array}$ & Cholesterol & $\begin{array}{l}\text { Serum } \\
\text { triglyceride }\end{array}$ & Treatment \\
\hline 26 & $6.20(1.02)^{*}$ & $2.45(2.12)$ & Nil \\
10 & $6.25(1.07)$ & $2.6(1.76)$ & Allopurinol \\
7 & $5.93(1.25)$ & $1.83(0.98)$ & $\begin{array}{l}\text { Azapropazone } \\
\text { Allopurinol and } \\
\text { azapropazone }\end{array}$ \\
1 & 5.9 & 2.95 & Nil \\
\hline
\end{tabular}

*Values are mean (SD).

of the blood samples. The enzymes for the coupled assay were obtained from Boehringer-Mannheim and all other chemicals were obtained from $\mathrm{BDH}$ Ltd, Poole, Dorset.

PRPP synthetase was assayed spectrophotometrically ${ }^{6}$ at $340 \mathrm{~nm}$ at $37^{\circ} \mathrm{C}$ continuously on a Vitatron rate analyser linked to a recorder. Glutathione reductase was assayed in the initial 1 in 17 haemolysate by a modification of the method of Lee Kum-Tatt et al. $^{7}$

\section{Results}

The mean enzymic activities of erythrocyte PRPP synthetase and GTR in the patients with gout and in the healthy controls are given in Table 1 . The data have been divided according to treatment and statistically analysed (Table 2). The effect of the two drugs, allopurinol and azapropazone, on serum uric acid, cholesterol, and triglyceride concentrations is given in Tables 3 and 4 .

\section{Discussion}

It is apparent from the results presented in Tables 1 and 2 that a highly significant $(p=0.001)$ increase in PRPP synthetase was found in patients with gout when compared with healthy controls after both groups had fasted overnight. In 10 patients treated with allopurinol the activity of this enzyme is essentially unchanged by treatment. Similarly, no change is seen in the seven patients taking azapropazone. Thus the significant increase in PRPP synthetase activity in these patients appears to be associated with their gout and is not attributable to either of the drugs used in this study. Moreover, the observed increase found in patients with gout cannot be explained by hyperuricaemia since it has been found earlier ${ }^{3}$ that although some increase in activity of this enzyme does occur in most hyperuricaemics, the clinical condition of gout produces the largest increase. Neither can the increase be attributed to an age difference in the two groups since no correlation has been found between age and enzymic activity. ${ }^{3}$ We have no evidence that the 10 patients with a positive family history of gout have higher enzymic activity than the other patients with gout (Table 1). Whereas inhibition of de novo synthesis may be one of the beneficial mechanisms of action of allopurinol and azapropazone, our results indicate that such inhibition does not occur at the level of PRPP synthetase.

The enzyme is reported to be a large aggregate of 32 polypeptide chains. ${ }^{8}$ The small aggregates appear to be inactive, whereas the aggregates of 16 and 32 subunits are active. Becker et al have indicated that the effect of small molecule activators and inhibitors appears to be correlated with their effect on the state of aggregation of the enzyme. ${ }^{9}$ This would appear to be a suitable area of investigation to explain the increased activity of PRPP synthetase we found in our gout population.

The data for glutathione reductase are more complex. When the untreated gout patients are compared with the controls (Tables 1 and 2) the reduction in glutathione reductase activity in gout appears to be insignificant $(p=0 \cdot 2)$. Three of the untreated gout patients, however, had very high glutathione reductase levels ( $>175$ compared with a mean value of $78.9 \mathrm{nmol} / \mathrm{mg}$ protein/h). If these high values are discarded from the statistical analysis a significant reduction in enzymic activity for the gout patients $(p=0.001$, Table 2$)$ is observed. It is difficult at this stage to justify rejection of these very high values in these untreated gout patients, but there is certainly a skew distribution of glutathione reductase activities in healthy populations ${ }^{310}$ which may, in time, be attributable to the presence of genetic variants of the enzyme. This seems to be improbable in our three patients since their very high enzymic activities returned to normal levels when treatment was resumed. Such a finding also eliminates age or sex as possible causes of the 
high activities, but these results demand a wider survey.

It is apparent from the results given in Table 3 that the serum uric acid concentration in patients with gout is reduced by chemotherapy using either allopurinol or azapropazone, but in this study the latter appears to be more effective than allopurinol.

The lipid profile of the gout population shows a significant amount of type IV hyperlipidaemia (seven of the 26 patients). In the normal control group seven subjects were normal and one had mild type IIb. It is not surprising that the mean serum cholesterol level of the patients with gout was neither affected by treatment nor differed appreciably from the control mean (Table 4). In contrast, the mean serum triglyceride concentration of the gout population was significantly higher than that found in the control group (Table 4). These findings are in agreement with those of previous workers, ${ }^{11-14}$ though we do not find an increase in type IIb hyperlipidaemia in our gout population as reported by Naito and MacKenzie. ${ }^{15}$

Our results thus suggest that in a well documented gout population the activity of PRPP synthetase is increased and could be one factor in producing the hyperuricaemia seen in these patients. The exact mechanism for this increase, which is unaffected by allopurinol or azapropazone, is not obvious from the present study, but the existence of a genetic variant of the enzyme cannot be excluded without further investigation. A reduced activity of glutathione reductase has been previously shown and may be a secondary effect associated with inflammation. This hypothesis is currently being investigated.

Financial assistance from the Sir Halley Stewart Trust (MW) and discussions with Dr Steven Shaw of Plymouth Polytechnic Statistics Department and Dr Francis Walker of A H Robins Co Ltd are gratefully acknowledged.

\section{References}

1 Sperling O, Boer P, Persky-Brosh S, Kanarek E, DeVries A. Altered kinetic property of erythrocyte phosphoribosyl pyrophosphate synthetase in excessive purine production. $\operatorname{Rev} \overrightarrow{\bar{N}}$ Eur Etudes Clin Biol 1972; 17: 703-6.

2 Becker M A, Meyer L J, Wood A W, Secgmiller J E. Purine overproduction in man associated with increased phosphoribosyl pyrophosphate synthetase activity. Science 1973; 179: 1123-6.

3 Hardwell T R, Braven J, Shaw S, Whittaker M. Phosphoribosyl pyrophosphate synthetase and glutathione reductase in erythro- ڤ cytes from hyperuricacmic and gout patients. Clin Chim Acta 1982; 126: 217-26.

4 Long W K. Red blood cell glutathione reductase in gout. Science 1962; 138: 991

5 Long W K. Glutathione reductase in red blood cells: variant associated with gout. Science $1967 ; 155$ : 712-3.

6 Braven J, Hardwell T R, Seddon R, Whittaker M. A ? spectrophotometric assay of phosphoribosyl pyrophosphate $\mathrm{c}$ synthetase. Ann Clin Biochem 1984; 21: 366-71.

7 Lee Kum-Tatt, It-Koon Tan, Ai-Mee Seet. A new colorimetric $\overrightarrow{-}$ method for the determination of NADH-NADPHdependent glutathione reductase in erythrocytes and in plasma. Clin Chim Acta 1975; 58: 101-8.

8 Fox I H, Kelley W N. Human phosphoribosyl pyrophosphate synthetase: distribution, purification and properties. $J$ Biol Chem 1971; 246: 5739-48.

9 Becker M A, Meyer L J, Huisman W H, Lazar C S, Adams W B. Human phosphoribosyl pyrophosphate synthetase: relation of activity and quaternary structure. In: Muller M, Kaiser E, O Seegmiller J E, eds. Purine metabolism in man. Vol. II. New York: Plenum, 1977: 71-9.

10 Salkie M L, Simpson E. The erythrocyte glutathione reductase activity (EC 1.6.4.2) of healthy blood donors. J Clin Pathol 1970; 23: 708-10.

11 Bluestone R, Lewis B, Mervant J. Hyperlipidaemia in goutt. Ann Rheum Dis 1971; 30: 134-7.

12 Gibson T, Grahame R. Gout and hyperlipidaemia. Ann Rheum Dis 1974; 33: 298-303.

13 Nishida Y, Akoaka I, Nishizawa T, Yoshimura T. Hyperlipidaemia in gout. Clin Chim Acta 1975; 62: 103-6.

14 Ferns G A A, Lanham J, Stocks J, Ritchie C, Katz J, Galton D $\overline{\bar{O}}$ $J$. The measurement of high density lipoprotein subfractions in patients with primary gout using a simple precipitation method. Ann Clin Biochem 1985; 22: 526-32.

15 Naito H K, MacKenzie A H. Secondary hypertriglyceridemia : and hyperlipoproteinemia in patients with primary asymptomatic gout. Clin Chem 1979; 25: 371-5. 